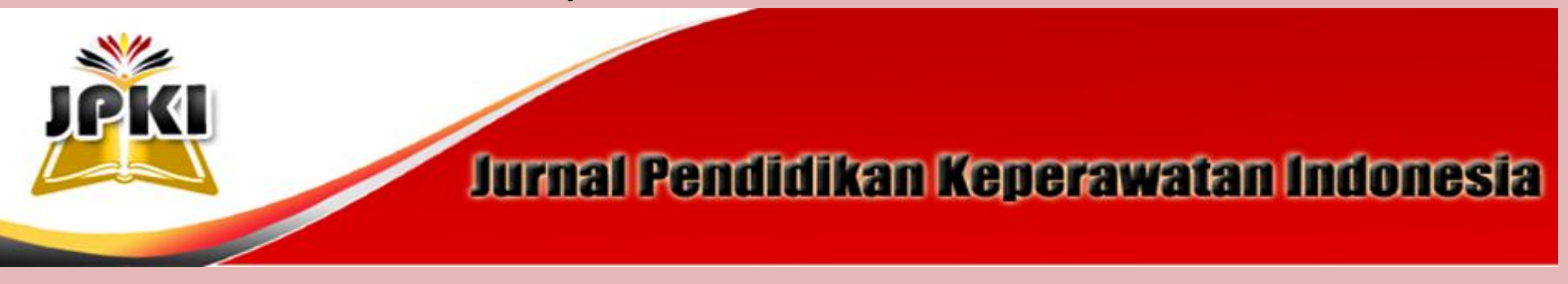

Journal homepage : http://ejournal.upi.edu/index.php/JPKI

\title{
PERBEDAAN TEKANAN DARAH SEBELUM DAN SESUDAH PEMBERIAN TEKNIK RELAKSASI IMAJINASI TERBIMBING PADA LANSIA YANG MENDERITA HIPERTENSI
}

\author{
${ }^{1}$ Sri Sumartini, Heru Hari Bachtiar \\ ${ }^{1}$ Prodi D3 Keperawatan FPOK Universitas Pendidikan Indonesia \\ Email : ${ }^{1}$ srisumartini@upi.edu
}

\begin{abstract}
ABSTRAK
Penyakit hipertensi pada Lansia memerlukan penanganan tanpa menimbulkan efek samping yang bertujuan untuk mencegah terjadinya morbiditas dan mortalitas serta mempertahankan tekanan darah normal. Salah satu teknik yang dapat digunakan adalah teknik relaksasi imajinasi terbimbing (guided imaginary). Penelitian ini bertujuan untuk mengetahui perbedaan tekanan darah sebelum dan sesudah pemberian teknik relaksasi imajinasi terbimbing pada Lansia yang menderita hipertensi. Penelitian ini menggunakan desain penelitian eksperimental dengan pre-experiment design. Sampel dalam penelitian ini menggunakan tekhnik purposive sampling menggunakan sebanyak 30 orang Lansia yang mengalami hipertensi di Wilayah Kerja UPTD Puskesmas Kertajati Kabupaten Majalengka. Data ini diambil menggunakan lembar observasi tekanan darah. Setelah itu dilakukan uji statistik yang menggunakan uji beda yaitu Wilcoxon Signed Rank Test dengan tingkat kemaknaan 0,05. Hasil penelitian menunjukkan rata-rata tekanan darah sebelum pemberian teknik relaksasi imajinasi terbimbing sebesar 154,9 dan sebagian besar responden mengalami hipertensi Stadium I (60,0\%). Sementara rata-rata tekanan darah pada Lansia yang menderita hipertensi sesudah pemberian teknik relaksasi imajinasi terbimbing sebesar 143,3 dan sebagian besar responden mengalami prehipertensi (46,7\%). Hasil uji hipotesis menunjukkan ada perbedaan tekanan darah sebelum dan sesudah pemberian teknik relaksasi imajinasi terbimbing pada Lansia yang menderita hipertensi di Wilayah Kerja UPTD Puskesmas Kertajati Kabupaten Majalengka Tahun 2014 ( $\rho$ value $=0,008$ ). Oleh karena itu perawat di Puskesmas dapat mengaplikasikan teknik relaksasi imajinasi terbimbing dalam membantu menurunkan tekanan darah pada pasien yang mengalami hipertensi
\end{abstract}

Kata kunci : Tekanan Darah, Hipertensi, Imajinasi Terbimbing

\begin{abstract}
Hypertension of elderly needs handling without giving an effects for prevent morbidity and mortality and for maintain normal blood pressure. One of technique which can be used is a guided imaginary. The research is for determine differences of blood pressure before and after giving guided imaginary for elderly suffering hypertension. This research is used experimental with pre-experiment design. Sample in this research is purposive sampling technique method using as many as 30 people for the elderly that experienced hypertension in the work area of the UPTD Puskesmas Kertajati Majalengka. In this data is taken by using sheet of observation blood pressure. After that performed statistical test that using wilcoxon signed rank test with significance level 0,05.The result shows average is 154,9 and most of respondents have hypertension Stadium I (60,0\%). While, averages of elderly blood pressure is 143,3 after giving guided imaginary technique and most of respondents have prehypertension (46,7\%). The result of hypothesis test shows there are differences blood pressure before and after giving guided imaginary technique for elderly suffering hypertension in work area UPTD Puskesmas Kertajati Kabupaten Majalengka years 2014 (pvalue=0,008)Therefore, nurses in Puskesmas can apply guided imaginary technique for lowers blood pressure for patients who have hypertension.
\end{abstract}

Key words $\quad$ : Blood Pressure, Hypertension, Guided Imaginary 


\section{PENDAHULUAN}

Sehat merupakan hak setiap orang. Setiap orang mempunyai hak yang sama dalam memperoleh akses atas sumber daya di bidang kesehatan, memperoleh pelayanan kesehatan yang aman dan bermutu, serta berhak secara mandiri dan bertanggung jawab menentukan sendiri pelayanan kesehatan yang diperlukan bagi dirinya. Hal tersebut dilakukan agar terwujud derajat kesehatan masyarakat yang optimal.

Menurunnya derajat kesehatan masyarakat dalam rangka kegiatan perawatan kesehatan masyarakat diakibatkan oleh meningkatnya angka kesakitan pada keluarga. Sasaran khususnya adalah keluarga rawan, keluarga yang rentan terhadap masalah kesehatan.

Hal tersebut disebabkan karena adanya beberapa faktor antara lain meningkatnya suatu penyakit di masyarakat, kurangnya kegiatan perawatan kesehatan masyarakat oleh petugas, kurang akuratnya data yang tersedia dan lingkungan yang tidak sehat dan bersih. Penyakit degeneratif yang banyak terjadi di masyarakat dan mempunyai tingkat mortalitas yang cukup tinggi serta mempengaruhi kualitas hidup dan produktifitas seseorang salah satunya adalah penyakit hipertensi.

Menurut World Health Organization (WHO) prevalensi hipertensi di dunia pada tahun 2009 terdapat 982 juta orang atau $26,4 \%$ penduduk di dunia mengalami kejadian hipertensi. Angka ini kemungkinan akan meningkat menjadi 29,2\% di tahun 2025. Dari 982 juta pengidap hipertensi, 342 juta berada di negara maju dan 640 juta sisanya berada di negara sedang berkembang (Kementerian Kesehatan RI, 2011).

Penyakit hipertensi di Indonesia termasuk kedalam kelompok penyakit sepuluh besar di rumah sakit dengan angka kematian yang cukup tinggi. Pada tahun 2010 terdapat 100.489 kasus hipertensi terdiri dari 19.874 kasus rawat inap dan 80.165 kasus rawat jalan. Adapun angka kematian karena hipertensi esensial tercatat sebanyak 955 kematian dengan angka case fatality rate (CFR) sebesar $4,81 \%$. Sementara prevalensi hipertensi di Provinsi Jawa Barat berdasarkan Riset Kesehatan Dasar (Riskedas) tahun 2007 mencapai 47,8\% dan mengalami kenaikan pada tahun 2010 menjadi 52,5\% (Kementrian Kesehatan RI, 2012).

Penyakit hipertensi merupakan salah satu penyakit yang tidak diketahui penyebabnya secara pasti. Namun menurut Sustrani (2006) bahwa hipertensi esensial merupakan 95\% dari seluruh kasus hipertensi dan sisanya hipertensi sekunder yaitu tekanan darah tinggi yang penyebabnya dapat diklasifikasikan, diantaranya adalah kelainan organik seperti penyakit ginjal, kelainan pada korteks adrenal, pemakaian obat-obatan sejenis kortikosteroid, dan lain-lain.

Menurut Carpenito (2009) bahwa penyakit hipertensi atau penyakit tekanan darah tinggi terkadang tidak disadari oleh penderita. Dalam kenyataannya, 50\% penderita hipertensi tidak menunjukkan gejala yang jelas, apalagi bila masih dalam taraf awal. Gejala-gejala yang sering timbul antara lain pusing, sakit kepala, mimisan secara tiba-tiba dan tengkuk terasa pegal. Hipertensi tidak menunjukkan gejala awal, satu-satunya jalan untuk mengetahui adalah melakukan pengontrolan tekanan darah secara teratur.

Kejadian hipertensi perlu diwaspadai dan ditangani dengan tepat karena risikonya yang dapat menyebabkan kematian. Menurut Sani (2008) hipertensi mengakibatkan jantung bekerja lebih keras sehingga proses perusakan dinding pembuluh darah berlangsung dengan lebih cepat. Hipertensi meningkatkan resiko penyakit jantung dua kali dan meningkatkan resiko stroke delapan kali dibanding dengan orang yang tidak mengalami hipertensi. Selain itu hipertensi juga menyebabkan terjadinya payah jantung, gangguan pada ginjal dan kebutaan serta yang paling parah adalah efek jangka panjangnya yang berupa kematian mendadak.

Prevalensi penderita hipertensi pada usia lanjut (Lansia) yaitu yang berusia lebih dari 65 tahun sebesar $65-75 \%$ setiap tahunnya dan $16,2 \%$ mengalami hipotensi. Penyakit hipertensi pada Lansia akan terus meningkat yang disebabkan oleh peningkatkan kekakuan arteri. Disamping itu dengan bertambahnya usia berkaitan dengan penurunan fungsi kognitif dan psikomotor yang dapat mendorong meningkatnya hipertensi pada Lansia. Fungsi kognitif meliputi proses belajar, persepsi, pemahaman, pengertian, perhatian sehingga menyebabkan reaksi dan prilaku lansia. 
Sementara penurunan fungsi psikomotor meliputi hal-hal yang berhubungan dengan dorongan kehendak seperti gerakan, tindakan, koordinasi yang berakibat bahwa lansia menjadi kurang cekatan (Marliani, 2007).

Penyakit hipertensi pada Lansia memerlukan penanganan tanpa menimbulkan efek samping yang bertujuan untuk mencegah terjadinya morbiditas dan mortalitas serta mempertahankan tekanan darah normal (Muttaqin, 2008). Hal tersebut diperkuat oleh Smeltzer dan Bare dalam Carpenito (2009) bahwa tujuan penanganan pasien dengan hipertensi adalah menurunkan tekanan darah mendekati normal dan salah satu tindakan pengelolaan hipertensi adalah menggunakan non farmakologis yaitu menciptakan keadaan rileks dengan berbagai cara yang dapat mengontrol sistem saraf yang akhirnya mampu menurunkan tekanan darah.

Salah satu teknik yang dapat digunakan adalah teknik relaksasi imajinasi terbimbing (guided imaginary). Dengan menggunakan teknik ini yang merupakan suatu teknik untuk mengkaji kekuatan pikiran saat sadar maupun tidak sadar untuk dapat menciptakan bayangan gambar yang membawa ketenangan dan keheningan dapat digunakan sebagai sarana penyembuh dalam memulihkan kesehatan organ-organ yang mengalami penyakit dengan membayangkan organ tersebut dalam kondisi sehat (Carpenito, 2009). Hasil penelitian Fuad, Ismonah dan Meikawati (2011) menyatakan bahwa ada pengaruh pemberian teknik relaksasi imajinasi terbimbing terhadap tekanan darah pada pasien hipertensi di Wilayah Puskesmas Krobokan Semarang.

Berdasarkan Dinas Kesehatan Kabupaten Majalengka tahun 2012 kejadian hipertensi yaitu 45.187 kejadian terdiri dari 41.981 (92,9\%) hipertensi primer dan 3.206 $(7,1 \%)$ hipertensi sekunder. Pada saat penulis melakukan Praktek Komunitas di wilayah kerja UPTD Puskesmas Kertajati kejadian hipertensi di wilayah tersebut cukup banyak dan menurut data UPTD Puskesmas Kertajati sendiri kejadian hipertensi dari tahun ke tahun yang dialami oleh lansia selalu mengalami peningkatan. Jumlah kasus hipertensi pada Lansia di wilayah kerja UPTD Puskesmas Kertajati pada tahun 2011 sebanyak 355 orang dan pada tahun 2012 menjadi 484 orang.

Pentingnya kajian mengenai hipertensi ini maka penulis tertarik untuk melakukan penelitian tentang "Perbedaan tekanan darah sebelum dan sesudah pemberian teknik relaksasi imajinasi terbimbing pada Lansia yang menderita hipertensi di Wilayah Kerja UPTD Puskesmas Kertajati Kabupaten Majalengka Tahun 2014".

\section{METODOLOGI}

Penelitian ini menggunakan desain penelitian eksperimental dengan preexperiment design. Dengan jenis desain one group pretest-posttest design, dimana desain ini tidak ada kelompok pembanding (kontrol), tetapi sudah dilakukan observasi pertama (pretest) yang memungkinkan penelitian dapat menguji perubahan-perubahan yang terjadi setelah adanya eksperimen (program) (Notoatmodjo, 2010).

Populasi dalam penelitian ini adalah seluruh Lansia yang mengalami hipertensi di Wilayah Kerja UPTD Puskesmas Kertajati Kabupaten Majalengka sebanyak 484 orang. Pengambilan sampel sebanyak 30 orang Lansia dalam penelitian ini menggunakan teknik purposive sampling.

Pengumpulan data dalam penelitian ini dilakukan untuk mengukur tekanan darah responden sebelum dan sesudah teknik relaksasi imajinasi terbimbing. Mengukur tekanan darah responden menggunakan alat yang disebut dengan tensimeter. Adapun pelaksanaan teknik relaksasi imajinasi terbimbing untuk setiap responden dilakukan sebanyak 3 kali perlakuan dengan waktu antara 5-15 menit per perlakuan, jeda waktu antara perlakuan pertama, kedua dan ketiga yaitu 1 hari.

\section{HASIL DAN PEMBAHASAN}

Tekanan Darah Sebelum Pemberian Teknik Relaksasi Imajinasi Terbimbing pada Lansia yang Menderita Hipertensi 
Diagram 1. Tekanan Darah Sebelum Pemberian Teknik Relaksasi Imajinasi Terbimbing pada Lansia yang Menderita Hipertensi

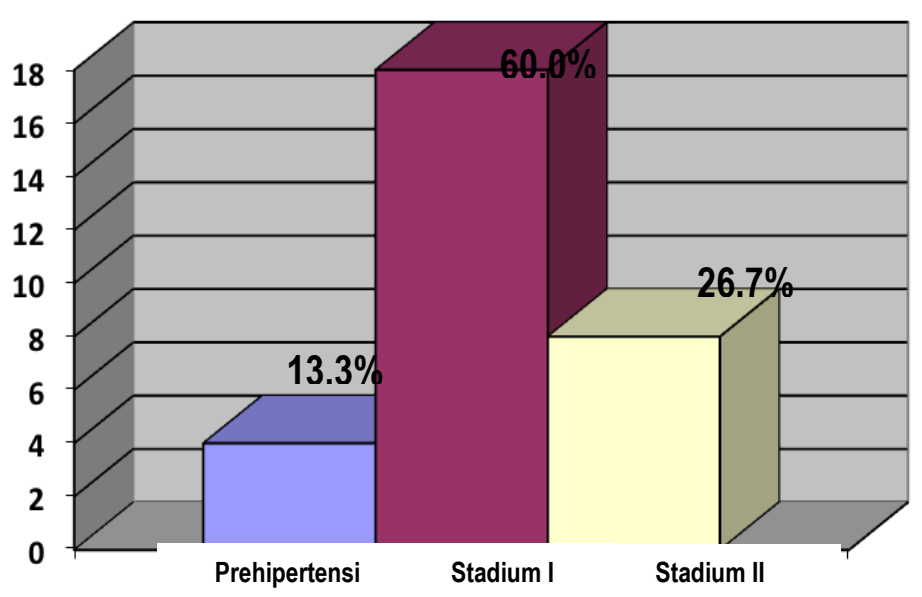

Berdasarkan diagram 1 menunjukan bahwa Lansia yang menderita hipertensi sebelum pemberian teknik relaksasi imajinasi terbimbing lebih dari setengah mengalami hipertensi stadium I, kurang dari setengah mengalami hipertensi stadium II dan sebagian kecil mengalami prehipertensi. Pengukuran tekanan darah dalam penelitian ini dilakukan sebanyak 3 kali $\left(\mathrm{X}_{1}, \mathrm{X}_{2}\right.$ dan $\left.\mathrm{X}_{3}\right)$ dengan jeda masingmasing tekanan darah adalah 1 hari karena perlakuan teknik relaksasi imajinasi terbimbing diberikan pada responden dengan jeda 1 hari. Rata-rata sistolik $X_{1}$ sebesar 166, rata-rata $X_{2}$ sebesar 153 dan rata-rata $X_{3}$ sebesar 146. Tekanan darah semakin menurun seiring dengan pemberian perlakukan atau intervensi. Gambaran hasil pengukuran masingmasing tekanan darah sebelum perlakuan dapat dilihat pada grafik berikut:
Grafik 1. Tekanan Darah Sebelum Pemberian Teknik Relaksasi Imajinasi Terbimbing pada Lansia yang Menderita Hipertensi $\left(X_{1}, X_{2}\right.$ dan $\left.X_{3}\right)$

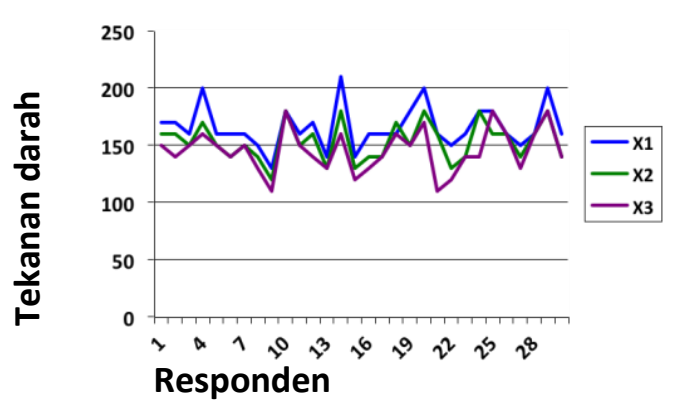

Dari ketiga tekanan darah (sistolik) nilai rata-ratanya digabung dan dirataratakan kembali. Nilai rata-rata tekanan darah (sistolik) secara keseluruhan dapat dilihat pada tabel berikut:

Tabel $1 \quad$ Distribusi $\quad$ Statistik Tekanan Darah pada Lansia yang Menderita Hipertensi Sebelum Pemberian Teknik Relaksasi Imajinasi Terbimbing $\mathbf{N}=30$

\begin{tabular}{cccc}
\hline Variabel & Mean & SD & Min_Max \\
\hline $\begin{array}{c}\text { Tekanan } \\
\text { darah sebelum } \\
\text { perlakuan }\end{array}$ & 154,9 & 16,784 & $120-187$ \\
\hline
\end{tabular}

Hasil penelitian menunjukkan ratarata tekanan darah (sistolik) sebelum pemberian teknik relaksasi imajinasi terbimbing rata-ratanya sebesar 154,9 dengan standar deviasi 16,784, nilai terendah sebesar 120 dan tertinggi sebesar 187.

Tekanan Darah Sesudah Pemberian Teknik Relaksasi Imajinasi Terbimbing pada Lansia yang Menderita Hipertensi

Diagram batang berikut ini menggambarkan tekanan darah sesudah dilakukan pemberian teknik relaksasi imajinasi terbimbing. 
Diagram 2. Tekanan Darah Sesudah Pemberian Teknik Relaksasi Imajinasi Terbimbing pada Lansia yang Menderita Hipertensi

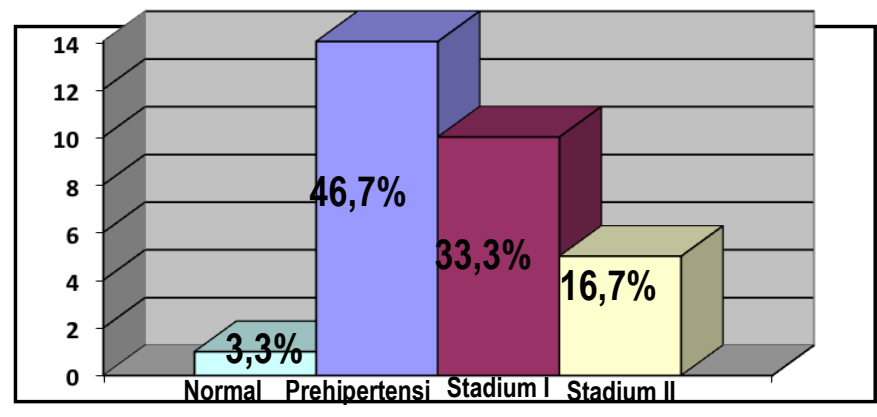

Berdasarkan diagram 2 menunjukan bahwa Lansia yang menderita hipertensi sesudah pemberian teknik relaksasi imajinasi terbimbing kurang dari setengah mengalami prehipertensi, kurang dari setengah mengalami hipertensi stadium I dan sebagian kecil mengalami stadium II, juga terdapat sebagian kecil mengalami tekanan darah normal.

Pengukuran tekanan darah sesudah pemberian teknik relaksasi imajinasi terbimbing dilakukan sebanyak 3 kali $\left(X_{1}\right.$, $\mathrm{X}_{2}$ dan $\mathrm{X}_{3}$ ) dengan jeda masing-masing tekanan darah adalah 1 hari. Rata-rata sistolik $X_{1}$ sebesar 152 , rata-rata $X_{2}$ sebesar 141 dan rata-rata $X_{3}$ sebesar 137 . Tekanan darah semakin menurun seiring dengan pemberian perlakukan atau intervensi. Pada grafik dibawah ini terlihat tekanan darah semakin menurun dari perlakuan 1 sampai ke perlakuan 3 .

Grafik 2. Tekanan Darah Sesudah Pemberian Teknik Relaksasi Imajinasi Terbimbing pada Lansia yang Menderita Hipertensi $\left(X_{1}, X_{2} \operatorname{dan} X_{3}\right)$

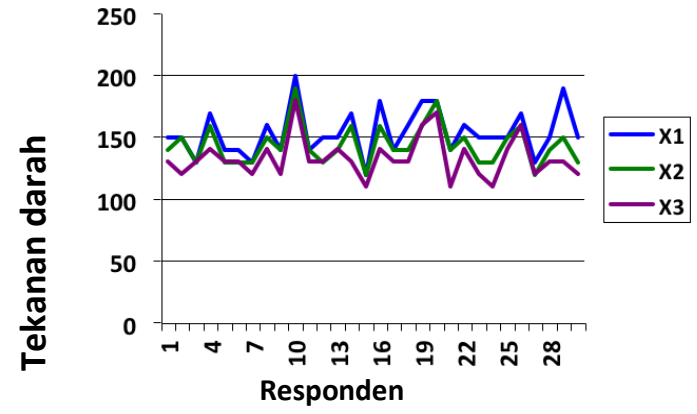

Jurnal Pendidikan Keperawatan Indonesia 2(1) : 1-9 (2016)
Dari ketiga tekanan darah (sistolik) nilai rata-ratanya digabung dan dirataratakan kembali. Nilai rata-rata tekanan darah (sistolik) secara keseluruhan dapat dilihat pada tabel berikut:

Tabel 2. Distribusi Statistik Tekanan Darah pada Lansia yang Menderita Hipertensi Sesudah Pemberian Teknik Relaksasi Imajinasi Terbimbing

\begin{tabular}{cccc}
\hline Variabel & Mean & SD & Min_Max \\
\hline $\begin{array}{c}\text { Tekanan } \\
\text { darah }\end{array}$ & & & \\
$\begin{array}{c}\text { sesudah } \\
\text { perlakuan }\end{array}$ & 143,3 & 15,676 & $117-190$ \\
\hline
\end{tabular}

Hasil penelitian menunjukkan ratarata tekanan darah (sistolik) sesudah pemberian teknik relaksasi imajinasi terbimbing rata-ratanya sebesar 143,3 dengan standar deviasi 15,676, nilai terendah sebesar 117 dan tertinggi sebesar 190.

Perbedaan Tekanan Darah Sebelum dan Sesudah Pemberian Teknik Relaksasi Imajinasi Terbimbing Pada Lansia yang Menderita Hipertensi

Tabel 3. Perbedaan Tekanan Darah Sebelum dan Sesudah Pemberian Teknik Relaksasi Imajinasi Terbimbing

\begin{tabular}{ccccc}
\hline $\begin{array}{c}\text { Tekanan darah } \\
\text { sebelum dan } \\
\text { sesudah }\end{array}$ & N & $\begin{array}{c}\text { Mean } \\
\text { Rank }\end{array}$ & $\begin{array}{c}\text { Sum of } \\
\text { Ranks }\end{array}$ & $\begin{array}{c}\boldsymbol{\rho} \\
\text { valu } \\
\boldsymbol{e}\end{array}$ \\
\cline { 1 - 4 } Negative Ranks & $18(\mathrm{a})$ & 11,22 & 202,00 & \\
\cline { 1 - 3 } Positive Ranks & 4(b) & 12,75 & 51,00 & 0,008 \\
\cline { 1 - 4 } Ties & 8(c) & & \multicolumn{2}{c}{} \\
\cline { 1 - 3 }
\end{tabular}

Berdasarkan tabel 3 diketahui bahwa dari 30 responden terdapat responden yang mengalami penurunan tekanan darah setelah pemberian teknik relaksasi imajinasi terbimbing sebanyak 18 orang, 
yang tidak mengalami peningkatan tekanan darah setelah pemberian teknik relaksasi imajinasi terbimbing sebanyak 4 orang dan yang tekanan darahnya tidak mengalami perubahan setelah pemberian teknik relaksasi imajinasi terbimbing sebanyak 8 orang.

Hasil uji dengan uji beda Wilcoxon Signed Rank Test diperoleh $\rho$ value = 0,008 dengan $\alpha=0,05$ ( $p$ value $<\alpha$ ) sehingga hipotesis nol ditolak yang berarti ada perbedaan tekanan darah sebelum dan sesudah pemberian teknik relaksasi imajinasi terbimbing pada Lansia yang menderita hipertensi di Wilayah Kerja UPTD Puskesmas Kertajati Kabupaten Majalengka Tahun 2014.

\section{Tekanan Darah Sebelum Pemberian Teknik Relaksasi Imajinasi Terbimbing pada Lansia yang Menderita Hipertensi}

Hasil penelitian menunjukkan bahwa Lansia yang menderita hipertensi sebelum pemberian teknik relaksasi imajinasi terbimbing lebih dari setengah mengalami hipertensi stadium I yaitu sebesar 60,0\%, kurang dari setengah mengalami hipertensi stadium II yaitu sebesar $26,7 \%$ dan sebagian kecil mengalami prehipertensi yaitu sebesar $13.3 \%$. Secara objektif pada saat penelitian, klien terlihat gelisah, lelah dan nafas terasa berat namun masih bisa mendengar dan mengikuti perintah dengan baik. Melalui pengukuran tekanan darah (sistolik) diperoleh bahwa tekanan darah yang dialami klien diperoleh minimal 120 dan maksimal 187.

Menurut Sani (2008) hipertensi mengakibatkan jantung bekerja lebih keras sehingga proses perusakan dinding pembuluh darah berlangsung dengan lebih cepat. Hipertensi meningkatkan resiko penyakit jantung dua kali dan meningkatkan resiko stroke delapan kali dibanding dengan orang yang tidak mengalami hipertensi. Selain itu hipertensi juga menyebabkan terjadinya payah jantung, gangguan pada ginjal dan kebutaan serta yang paling parah adalah efek jangka panjangnya yang berupa kematian mendadak.

Pengukuran tekanan darah dilakukan sebanyak 3 kali dan menunjukkan bahwa tekanan darah klien semakin menurun seiring dengan pemberian perlakukan atau intervensi yaitu rata-rata sistolik I sebesar 166, rata-rata sistolik II sebesar 153 dan rata-rata sistolik III sebesar 146. Sementara rata-rata dari ketiga hasil tersebut diperoleh sebesar 154,9. Hasil penelitian lebih rendah dibanding dengan hasil penelitian Sari (2010) di Rumah Sakit Dr. Kariadi Semarang mendapatkan bahwa rata-rata tekanan darah sebelum perlakuan sebesar 165.

Perlunya suatu perlakuan atau intervensi yang dapat menurunkan atau mengurangi tekanan darah pada klien yang mengalami hipertensi salah satunya dengan teknik relaksasi imajinasi terbimbing.

Tekanan Darah Sesudah Pemberian Teknik Relaksasi Imajinasi Terbimbing pada Lansia yang Menderita Hipertensi

Setelah diberikan perlakuan atau intervensi dengan pemberian teknik relaksasi imajinasi teribimbing, ditemukan klien dengan tekanan darah normal dan yang mengalami prehipertensi mengalami penambahan menjadi $46,7 \%$ sementara yang mengalami stadium I dan II mengalami penurunan masing-masing sebesar $33,3 \%$ dan $16,7 \%$.

Rata-rata tekanan darah (sistolik) sesudah pemberian teknik relaksasi imajinasi terbimbing rata-ratanya sebesar 143,3 dan nilai terendah sebesar 117 dan tertinggi sebesar 190. Hasil penelitian ini lebih rendah dibanding dengan hasil penelitian Sari (2010) di Rumah Sakit Dr. Kariadi Semarang mendapatkan bahwa rata-rata tekanan darah sebelum perlakukan sebesar 152. Juga lebih rendah dibanding hasil penelitian Fuad, Ismonah dan Meikawati (2011) di Wilayah Puskesmas Krobokan Semarang diperoleh rata-rata 
tekanan darah setelah perlakuan sebesar 148.

Penyakit hipertensi pada Lansia
memerlukan menimbulkan efek samping yang bertujuan untuk mencegah terjadinya morbiditas dan mortalitas serta mempertahankan tekanan darah normal. Menurut Carpenito (2009) bahwa salah satu teknik yang dapat digunakan adalah teknik relaksasi imajinasi terbimbing (guided imaginary). Dengan menggunakan teknik ini yang merupakan suatu teknik untuk mengkaji kekuatan pikiran saat sadar maupun tidak sadar untuk dapat menciptakan bayangan gambar yang membawa ketenangan dan keheningan dapat digunakan sebagai sarana penyembuh dalam memulihkan kesehatan organ-organ yang mengalami penyakit dengan membayangkan organ tersebut dalam kondisi sehat.

Menurut Smeltzer dan Bare dalam Carpenito (2009) tujuan penanganan pasien dengan hipertensi adalah menurunkan tekanan darah mendekati normal dan salah satu tindakan pengelolaan hipertensi adalah menggunakan non farmakologis yaitu menciptakan keadaan rileks dengan berbagai cara yang dapat mengontrol sistem saraf yang akhirnya mampu menurunkan tekanan darah.

Hasil penelitian ini dengan pemberian teknik relaksasi terbimbing, tekanan darah pada Lansia yang mengalami hipertensi dapat mengalami penurunan meskipun ada beberapa Lansia tidak mengalami perubahan tekanan darah. Keberhasilan pemberian teknik relaksasi terbimbing ini tentunya tidak terlepas dari faktor petugas yang memimpin teknik relaksasi, lingkungan yang tenang dan nyaman serta kondisi pasien Lansia itu sendiri. Seorang petugas yang memimpin teknik relaksasi pada kliennya harus menguasai prosedur teknik relaksasi serta memperhatikan waktu pelaksanaan agar manfaat dari pemberian teknik relaksasi terbimbing ini dapat dirasakan oleh klien. Disamping itu, keadaan lingkungan serta kondisi pasien dapat mempengaruhi Jurnal Pendidikan Keperawatan Indonesia 2(1) : 1-9 (2016) keberhasilan pemberian teknik relaksasi terbimbing. Tempat untuk pemberian teknik relaksasi harus dipilih dan disiapkan sesuai dengan kebutuhan relaksasi.

\section{Perbedaan Tekanan Darah Sebelum dan Sesudah Pemberian Teknik Relaksasi Imajinasi Terbimbing Pada Lansia yang Menderita Hipertensi}

Hasil penelitian ini diketahui bahwa ada perbedaan tekanan darah sebelum dan sesudah pemberian teknik relaksasi imajinasi terbimbing pada Lansia yang menderita hipertensi di Wilayah Kerja UPTD Puskesmas Kertajati Kabupaten Majalengka Tahun 2014.

Hasil penelitian ini sejalan dengan pendapat Carpenito (2009) dalam konsep keperawatan, penurunan tekanan darah pada hipertensi dapat menggunakan penatalaksanaan dengan penerapan non farmakologi, salah satunya dengan teknik relaksasi. Salah satunya teknik relaksasi imajinasi terbimbing (guided imaginary) yang dapat digunakan pada berbagai keadaan seperti hipertensi. Teknik ini merupakan teknik yang membantu mencapai relaksasi terdalam, selain itu juga merupakan media sederhana dan tidak memerlukan biaya tambahan untuk meningkatkan kemampuan koping.

Juga sejalan dengan pendapat Potter and Perry (2009) bahwa relaksasi pernapasan memberi respon melawan mass discharge (pelepasan impuls secara massal). Pada respon stress dari sistem saraf simpatis. Kondisi menurun tahanan perifer total akibat penurunan tonus vasokontriksi arteriol. Penurunan vasokontriksi arteriol memberi pengaruh pada perlambatan aliran darah yang melewati arteriol dan kapiler, sehingga memberi cukup waktu untuk mendistribusi oksigen dan nutrien ke sel, terutama jaringan otak atau jantung dan menyebabkan metabolisme sel menjadi lebih baik karena produksi energi ATP meningkat. Pernapasan lamban menarik nafas panjang dan membuangnya dengan 
nafas pelan-pelan juga memicu terjadi sinkronisasi getaran seluruh sel tubuh dan gelombang medan bioelektrik pun menjadi sangat tenang. Menurut Smeltzer dan Bare (2002) dalam Muttaqin (2008) imajinasi terbimbing dapat mengurangi tekanan dan berpengaruh terhadap proses fisiologi seperti menurunkan tekanan darah, nadi dan respirasi. Hal itu karena teknik imajinasi terbimbing dapat mengaktivasi sistem saraf parasimpatis.

Pada penelitian ini, masih terdapat Lansia setelah pemberian teknik relaksasi terbimbing, tekanan darahnya tidak mengalami penurunan hal ini dapat dikarenakan beberapa faktor diantaranya tempat yang kurang tenang dan nyaman serta kondisi Lansia mengalami penyakit komplikasi. Dalam teknik relaksasi, penyiapan tempat yang tenang dan nyaman sangat menentukan keberhasilan pemberian teknik relaksasi, karena dengan menciptakan ketenanganan dan kenyamanan maka pelaksanaan dari pemberian teknik relaksasi dapat dilakukan sesuai dengan prosedur dan tujuan dari teknik relaksasi ini dapat tercapai. Sementara apabila Lansia mengalami penyakit komplikasi akan menjadi faktor pengganggu yang dapat menghambat keberhasilan proses relaksasi, karena Lansia menjadi kurang siap atau memahami proses relaksasi imajinasi terbimbing yang diberikan.

Hasil penelitian ini sejalan dengan hasil penelitian Fuad, Ismonah dan Meikawati (2011) yang menyatakan bahwa ada pengaruh pemberian teknik relaksasi imajinasi terbimbing terhadap tekanan darah pada pasien hipertensi di Wilayah Puskesmas Krobokan Semarang. Persamaan hasil penelitian tersebut dengan penelitian ini adalah objek dan tujuan penelitian yaitu sama-sama respondenya adalah Lansia yang mengalami hipertensi dan bertujuan untuk mengetahui apakah ada kaitannya antara pemberian teknik relaksasi imajinasi terbimbing terhadap tekanan darah. Namun perbedaannya terletak pada desain penelitian, dimana pada penelitian Fuad, Ismonah dan Meikawati (2011) desain yang digunakan adalah desain penelitian korelasional yang hanya mengukur tekanan darah setelah pemberian perlakuan.

Berdasarkan hasil penelitian ini diharapkan dapat memberikan motivasi pada perawat untuk memberikan intervensi keperawatan teknik relaksasi imajinasi terbimbing pada klien yang mengalami hipertensi untuk membantu mengurangi tekanan darah yang dialami klien. Diharapkan setelah diberikan intervensi pada klien, klien dapat mempraktekannya sendiri di rumah bersama anggota keluarganya ketika mengalami atau merasakan tekanan darahnya naik kembali. Bagi pihak Puskesmas hasil penelitian ini diharapkan dapat memberikan masukan dan pertimbangan dalam membuat kebijakan terkait dengan pananganan klien yang mengalami hipertensi dengan membuat protap penatalaksanaan penurunan tekanan darah dengan teknik relaksasi imajinasi terbimbing dan lain sebagainya.

\section{SIMPULAN}

Ada perbedaan tekanan darah sebelum dan sesudah pemberian teknik relaksasi imajinasi terbimbing pada Lansia yang menderita hipertensi di Wilayah Kerja UPTD Puskesmas Kertajati Kabupaten Majalengka Tahun 2013 ( $\rho$ value $=0,008$ )

\section{DAFTAR PUSTAKA}

Arikunto, S. (2006). Prosedur Penelitian: Suatu Pengantar Praktik. Jakarta: Rineka Cipta.

Carpenito, L. J. (2009). Diagnosis Keperawatan: Aplikasi Pada Praktik Klinis. Jakarta: EGC.

Dinas Kesehatan Kabupaten Majalengka. (2012). Data Hipertensi di Kabupaten Majalengka tahun 2012. Majalengka: Dinas Kesehatan Kabupaten Majalengka. 
Fuad, Ismonah dan Meikawati (2011). Pengaruh Pemberian Teknik Relaksasi Imajinasi Terbimbing terhadap Tekanan Darah di Wilayah Puskesmas Krobokan Semarang. Semarang: Fakultas Kesehatan Universitas Muhammadiyah Semarang.

Guyton dan Hall. (2007). Buku Ajar Fisiologi Kedoteran. Jakarta: EGC

Kementrian Kesehatan RI. (2012). Data Kesehatan Indonesia Tahun 2011. Jakarta: Kementrian Kesehatan RI.

Kozier dan Erb. (2009). Buku Ajar Fundamental Keperawatan; Konsep, Proses dan Praktik. Edisi 7. Volume 1. Alih Bahasa Pamilih Eko Karyunani. Jakarta: EGC.

Marliani, L. (2007). Hipertensi dan Permasalahannya. Jakarta: PT Elex Media Komputindo Gramedia.

Maryam, dkk. (2008). Mengenal Usia Lanjut dan Perawatanya. Jakarta: Salemba Medika.

Mubarak. (2009). Menjaga Keseimbangan Kualitas Hidup Para Lanjut Usia. Jakarta: PT Gamedia Pustaka Umum.

Muttaqin, A. (2008). Pengantar Asuhan Keperawatan Klien dengan Gangguan Sistem Kardiovaskuler. Jakarta: Salemba Medika.

Notoatmodjo, S. (2010). Metodologi Penelitian Kesehatan. Jakarta: Rineka Cipta.

Nugroho, W. (2009). Komunikasi dalam Keperawatan Gerontik. Jakarta: EGC.

Potter dan Perry. (2009). Buku Ajar Fundamental Keperawatan. Buku 2 . Edisi 7. Alih Bahasa dr. Adrina Ferderika Nggie dan dr. Marina Albar. Jakarta: Salemba Medika.

Sani, A. (2008). Hypertension: Current Perspective. Jakarta: Media Crea

Sari, N. K. (2012). Perbedaan Tekanan Darah setelah Pemberian Teknik Relaksasi Nafas di Rumah Sakit Dr. Kariadi Semarang. Skripsi. Fakultas Kedokteran Universitas Dipenogoro.
Santoso, H., dan Ismail, H. (2009). Memahami Krisis Lanjut Usia: Uraian Medis dan PedagogisPastoral. Cet.1. Jakarta: Gunung Mulia.

Setiawati dan Bustami. (2005). Anti Hipertensi dalam Farmakologi dan Terapi. Jakarta: FKUI.

Smeltzer, S., C. and B. Bare, G. (2002). Buku Ajar Keperawatan Medikal Bedah. Jakarta, Buku Kedokteran EGC.

Shanty, M. (2011). Penyakit yang Diamdiam Mematikan. Yogyakarta: Javalitera.

Sustrani, L. (2006). Hipertensi. Jakarta: Gramedia Pustaka Utama.

Sutanto. (2009). Awas Tujuh Penyakit Degeneratif. Yogyakarta: Paradigma Indonesia.

Tamher, S. (2009). Kesehatan Usia Lanjut dengan Pendekatan Asuhan Keperawatan. Jakarta: Salemba Medika.

UPTD Puskesmas Kertajati. (2012). Data Pasien Hipertensi di Puskesmas Kertajati Kabupaten Majalengka tahun 2012. Majalengka: UPTD Puskesmas Kertajati.

Tamsuri, A. (2007). Konsep dan penatalaksanaan nyeri. Jakarta : EGC.

Walton, R. 1999. Perawatan Luka dan Penderita Perlukaan Ganda, Alih bahasa. Sonny Samsudin, Cetakan I. Jakarta : EGC

Zatsik \& Dimsdale, 1999. Seri Pedoman Praktis Keperawatan Medikal Bedah, (Edisi II). Jakarta: Penerbit Buku Kedokteran. EGC. 